\title{
EMPOWERMENT of WOMEN COMMUNITY THROUGH PROCESSING of BANANA CHIPS
}

\author{
Diny Agustini Sandrasari \\ Universitas Sahid, Indonesia \\ dinysandra@gmail.com
}

\begin{abstract}
Women's participation to improve the family economic is through an entrepreneurship. One of the business have done by women's in Cipayung area is to make a banana chips. Banana chips that they have produced have a savory and crispy taste but it has no longer. However, even though the business has been operating more than 5 years, that business not expanded. That is caused by low technology that they are used such as the slicing process, they still do this process manually so that it has unequal thickness, they used plastic to packaging the product with a simple seal so easy to broken and can make the product will be rancid quickly. The method used in this community development activity is participation of women's community who have banana chips business in Cipayung subdistrict, East Jakarta. This activity begins with a discussion with the community to identifying the problems, determine priority issues that must be endured resolved. The results of discussion is they agreed the main problem about the business is slicing process and packaging. To complete this problem which is an obstacle about the slicing process, it must be made with banana slicer machine, while for the packaging problem, improved packaging and labeling system must be done which aims to increase the production process of banana chips. The results showed that the introducing of technology will increased the production capacity and income of the community by $40 \%$.
\end{abstract}

Keywords : Empowerment, Women's Community, Banana Chips

\section{INTRODUCTION}

Bananas are tropical fruits belonging to the genus Musa and the family Musaceae. Bananas are popular and nutritious fruit, with a pleasant flavor. They are high energy fruit rich in carbohydrates and also good source of potassium, iron, phosphorous, vitamin C and B6. Generally, bananas are eaten raw but ripe banana is perishable and deteriorates rapidly after harvesting hence there is a need to apply an appropriate post-harvest technology to prolong the shelf life of the fruit. In order to minimize huge economic losses, banana can be preserved and processed by frying that name is banana chips.

Banana chips are snacks made from slices of bananas, commonly fried in oil. It can be covered with sugar or honey and have a sweet, salty or spicy taste. Deep fat frying is a conventional frying method for banana chip production, basically it includes the immersion of banana slices in a vegetable oil at temperature of around $110-160^{\circ} \mathrm{C}$ that causes drying by means of frying. The high temperature causes an evaporation of the water, which moves away from food and through the surrounding oil. Oil is absorbed by food, replacing some of lost water.

The community of women involved in community empowerment activities is a joint group that makes banana chips. They business has begun production since five years ago. The business is carried out by housewives. In one group consist of 5 people and they work form 10.00 am to $15.00 \mathrm{pm}$. The production of banana chips made by women's community is still uses traditional methods, both the tools and production process.

To developed banana chips home industry in Cipayung sub-district, we done through it extension program. The assessment includes existing technologies used and production capacity. During the evaluation, it was found out that the problems on the tool used in their production. The problems were (1) high risk on the part of the worker doing the banana slicing or cutting, (2) low efficiency (in term of productivity, difficulty and time consuming), (3) unsanitary. The average volume production of their industry is 20 bunches of banana per month that produced an average of 1.200 packs of banana chips per month. In order to sustain the growth of the industry, product quality has to be improved through upgraded processing equipment.

Based on observation, their banana chips product has been operating more than 5 years but that business not expanded. That is caused by low technology that they are used such as the slicing process, they still do this process manually so that it has unequal thickness. Packaging are also a problem in their business. They use plastic to package the product with a very simple sealed so the product are easy to broken and can make the product will be 
rancid quickly. Therefore, this empowerment aims to identify and solve the existing problems in banana chips processing.

\section{METHODS}

The method used in this community development activity is participation of women's community who have banana chips business in Cipayung sub-district, East Jakarta. This activity begins with a discussion with the community to identifying the problems, determine priority issues that must be endured resolved. The results of discussions with the community will be studied by the team to find a solution so that the appropriate solution given in solving community problems. Monitoring and evaluation are made to see result that have been done. Whether it is in accordance with what has been planned or not and to see the effectiveness of this community development program.

\section{RESULTS AND DISCUSSION}

Assesment of the existing operation of the banana chips home industry in Cipayung sub-district, East Jakarta

\section{Physical aspect}

The production area where processing of banana chips are done inside the vicinity of the owner's house. The kitchen is utilized for the cooking while the family area in the packaging of the product.
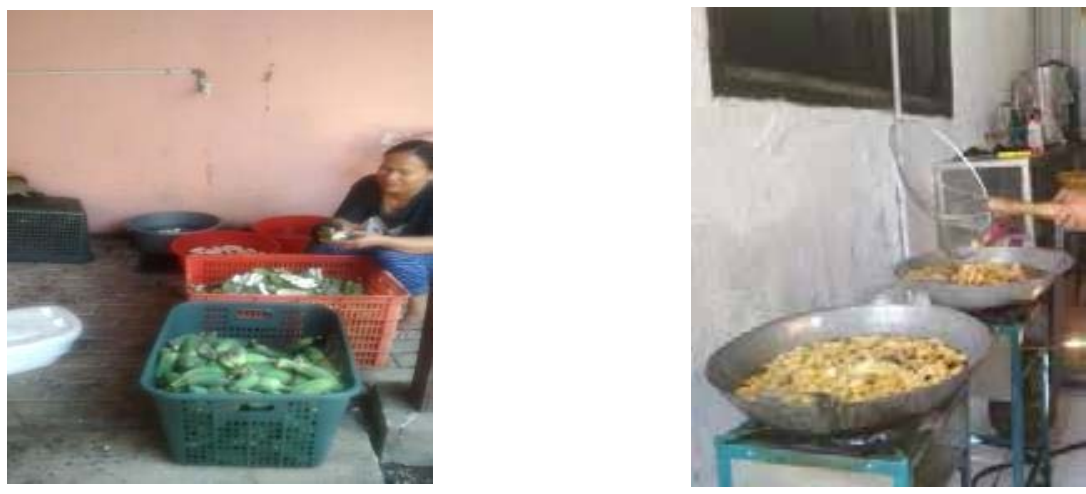

Picture 1. The production area are inside the vicinity of the owner's house

\section{Product distribution}

The product were sold in owner's house, stores, and eateries. Most of the products are also peddled in public transportation.

\section{Product promotion}

The owner's of this product rarely participate in local and regional trade exhibits and fairs in order to introduce ant promote its products to the buying public. Mostly depend on peddling to sell their products.

\section{Existing problems}

Based on discussion with the entrepreneurs showed that the problem faced by the banana chips home industry is the low production due the manual method used in slicing the chips. The manual banana slicer based on a wood planer concept. The structure is an inverted wooden-platform $(45 \mathrm{~cm} \times 20 \mathrm{~cm} \times 1.3 \mathrm{~cm})$ and fabricated sharpened flat iron $(18 \mathrm{~cm} \times 3.8 \mathrm{~cm} \times 0.2 \mathrm{~cm})$ permanently fixed to its platform. Slicing is being done by pushing the peeled banana over the sharpened portion of fabricated flat steel (Figure 2). 


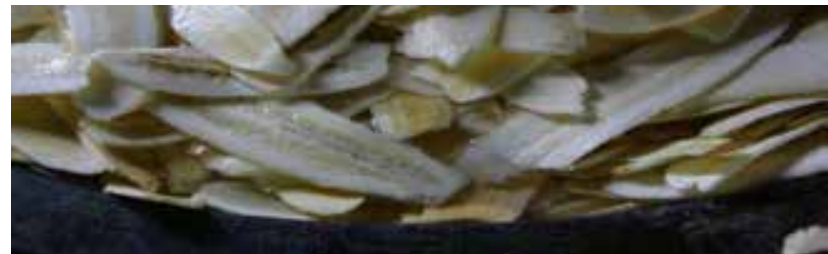

Picture 2 - The manual banana slicer being used by banana chips women's community in Cipayung sub-district, East Jakarta

According to the production, they cannot penetrate big markets since they cannot meet the demand of supply of the product in big market. Also, during project screening it was found out that they technology being used are risky on the part of the worker, is unsanitary due to rust and low efficient.

Another problem is packaging and labeling system of the product that need to be improved. The products are packed in ordinary plastics and sealed using gas lamps while other use a plastic heat sealer. The label on the hand, is also simple print out and inserted inside the plastic.

\section{Technology transfer of slicing machine in the banana chips}

During the activity, women's community who produce banana chips were trained on proper use and maintenance of the machine. A cooking demonstration was also done after the slicing of banana using the machine.

\section{Improvement of label design and packaging}

As part of the project, to overcome the problem of packaging and labeling, the extension agent submitted an application for the improved design of packaging of banana chips.
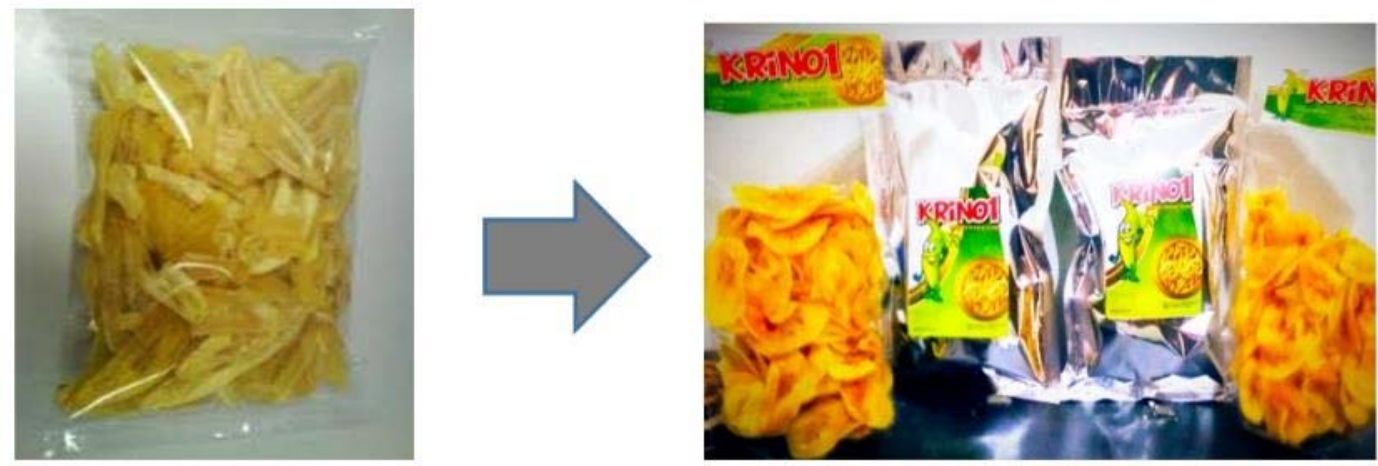

Picture 3. Improved design packaging of banana chips after empowerment activity

\section{Market plans/strategy}

With the upgraded technology using the bananas slicing machine, it will be able to increase its production and its deliveries to existing outlets and likewise allow them to establish new market outlets outside the region. The increased in production and an improved packaging and labeling system.

\section{The target production capacity}

With the utilization of the slicing machine, the productivity of the local producers in Cipayung sub-district, East Jakarta will increase and additional products will be processed. The current production capacity will be increased by $40 \%$ and the new production volume will be the following. With traditional and manual method, their capacity of banana chips are 1.200 pack/month, however with application of technology, the capacity has been increased become $1680 \mathrm{pack} / \mathrm{month}$. 


\section{Impact of technology of banana chips producers}

Technology has always been impacting of social community. Each invention has affected how people relate one to another and how cultures have expanded or ended. Impacts of technology could either have positive or negative effects. The introduction of technology through slicing machine, have more positive effect than negative. The positive impact was only showed on the increased income but also on its overall well-being including food, health and social.

\section{CONCLUSION}

With the introduction of new technology, the main impacts of the project rely on the increased productivity of producing banana chips and in turn increased their income. The low time input due to the use of technology is an advantage since producers can devote their time to other livelihood activities such as managing, selling and manning their stores. As of the moment, the project does not substantially alter their livelihood situation. Nevertheless, the project has strengths, it has help diversify their income sources and it represents a fairly significant source of income for most of the beneficiaries. The earnings enable families to spend more on food, school fees and health than they otherwise would.

\section{REFERENCES}

Irfan M A, Astuti S. 2014. Analysis of Inventory Control and Banana Chips Agroindustry Development Strategy in Bandar Lampung. Agroindustrial Journal Vol. 3 Issue 2 164-173

Moya V L. 2018. Leveraging technology and community partnerships in improving the banana chips industry in Brgy. Buray, Samar, Philippines. www.ssu.edu.ph.

Wani S A., Sharma V and Kumar P. 2017. Effect of processing parameters on quality attributes of fried banana chips. International Food Research Journal 24(4): 1407-1413 